\title{
MENELAAH ULANG POLIGAMI DALAM HUKUM PERKAWINAN
}

\author{
Ali Imron \\ Universitas Islam Negeri (UIN) Walisongo Semarang \\ e-mail: ali_imron@yahoo.com
}

\begin{abstract}
Marriage is essentially a reunification of men and women consisting of elements of soul and body are fused into one in a household frame for emotional and physical welfare. Regulation of marriage embraced the principle that a man may only have a wife and vice versa. The court may grant permission to the husband to a wife more than a certain requirements.Qualitative and quantitative Justice as a condition of polygamy difficult and even impossible to be realized. Polygamy is synonymous with the exploitation of women for the sake of greed and sexual lust.
\end{abstract}

Keywords: marriage; polygamy; islamic law

\section{A. Pendahuluan}

Perkawinan sebagaimana diatur dalam Undang-Undang Nomor 1 Tahun 1974 adalah ikatan lahir batin antara seorang pria dengan seorang perempuan sebagai suami isteri dengan tujuan membentuk keluarga (rumah tangga) yang bahagia dan kekal berdasarkan ketuhanan Yang Maha Esa. Kebahagiaan dalam rumah tangga sebagai tujuan perkawinan tercermin dari kesejahteraan lahir batin yang dirasakan oleh segenap anggota keluarga, baik suami, isteri, anak-anak, orang tua maupun mertua.

Hukum perkawinan yang berlaku di Indonesia menganut azas monogami terbuka, artinya dalam suatu perkawinan seorang pria hanya boleh mempunyai seorang isteri dan seorang perempuan hanya boleh mempunyai seorang suami. Akan tetapi dalam keadaan tertentu, pengadilan dapat memberi izin kepada seorang suami untuk beristeri lebih dari seorang apabila dikehendaki oleh pihak yang bersangkutan. Kalimat "apabila dikehendaki oleh pihak yang bersangkutan" mempunyai pengertian bahwa keinginan untuk beristeri lebih dari satu merupakan kehendak dari suami dan juga kehendak dari isteri atau isteri-isteri yang lain. Jadi ada peluang 
untuk melakukan poligami bagi suami dalam keadaan tertentu, dan tertutup peluang bagi isteri.

Untuk mendapatkan izin dari pengadilan untuk berpoligami diperlukan berbagai persyaratan baik administratif maupun subtantif. Untuk menilai kelayakan persyaratan poligami ini, para hakim di pengadilan memegang peranan kunci antara meloloskan ataukan tidak mengizinkan.

Tulisan ini bermaksud untuk mengetahui apa sebenarnya hakikat dari perkawinan, sejauh mana regulasi tentang perkawinan yang berlaku di Indonesia mengatur tentang poligami, dan mencari tahu nilai filosofis dari poligami perspektif keadilan gender.

\section{B. Hakikat Perkawinan}

Persoalan subordinasi, marginalisasi, serta pemiskinan terhadap perempuan dalam keluarga tidak akan terjadi apabila hakikat perkawinan dapat dipahami dengan tepat. Hakikat perkawinan tertinggi secara indah digambarkan dalam al-Qur'an surat al-A'raf [7] ayat 189 yang artinya: "Dialah yang menciptakan kamu dari diri yang satu dan dari padanya Dia menciptakan isterinya, agar dia merasa senang kepadanya. Maka setelah dicampurinya, isterinya itu mengandung kandungan yang ringan, dan teruslah ia merasa ringan (beberapa waktu). Kemudian tatkala dia merasa berat, keduanya (suami istri) bermohon kepada Allah, Tuhannya seraya berkata: Sesungguhnya jika engkau memberi kami anak yang shalih, tentulah kami termasuk orang-orang yang bersyukur."

Menurut ayat tersebut, perkawinan adalah penyatuan kembali pada bentuk asal kemanusiaan yang paling hakiki, yakni nafsin wahidah (diri yang satu). Allah sengaja menggunakan istilah nafsin wahidah karena dengan istilah ini ingin ditunjukkan bahwa pernikahan pada hakikatnya adalah reunifikasi antara laki-laki dan perempuan pada tingkat praktik implementatif, setelah didahului reunifikasi pada tingkat hakikat, yaitu kesamaan asal-usul kejadian umat manusia dari diri yang satu. Dengan adanya perkawinan maka dua sosok manusia beda jenis kelamin yang terdiri dari unsur jiwa dan raga menyatu menjadi satu dalam sebuah bingkai rumah tangga untuk mewujudkan apa yang disebut kesejahteraan lahir batin. Kata kunci hakikat perkawinan di sini menurut penulis adalah kesejahteraan lahir batin sebagai penterjemahan dari sakinah mawaddah wa rahmah.

Dengan pernikahan sebagai pengejawantahan dari reunifikasi kemanusiaan, di dalamnya seharusnya tidak diperhitungkan lagi antara 
kepentingan laki-laki pada satu pihak dan kepentingan perempuan pada pihak lain secara dominatif apalagi subordinatif oleh salah satu pihak. Antara laki-laki dan perempuan harus saling menganggap dirinya masingmasing sebagai unsur perekat dan penyatu, antara satu dengan lainnya tidak ada perbedaan, subordinasi, apalagi kepemilikan mutlak. Istilah yang paling pas menurut penulis adalah kamatsalil jasadi yaitu bagaikan satu tubuh yang tersusun secara terstruktur dan satu sama lain saling bergantung dan melengkapi.

Oleh karena itu, konsep pernikahan seharusnya juga dipahami sebagai penghargaan atas harkat dan martabat kemanusiaan. Isteri milik suami demikian juga suami milik isteri.

Dalam surat al-Rum [30] ayat 21 Allah berfirman yang artinya "Dan di antara tanda-tanda kekuasaan-Nya ialah Dia menciptakan untukmu isteri-isteri dari jenismu sendiri, supaya kamu cenderung dan merasa tentram kepadanya, dan dijadikan-Nya di antaramu kasih sayang. Sesungguhnya pada yang demikian itu benar-benar terdapat tanda-tanda bagi kaum yang berfikir".

Dalam ayat tersebut juga ditekankan keterkaitan antara kesatuan hakiki "min anfusikum" sebagai bentuk kesatuan pada level teoritis idealistis dengan kesatuan praktik implementatif (perkawinan) yang tenteram dan penuh kasih sayang. Ketenteraman dan kasih sayang ini tidak akan bisa diperoleh kalau satu dengan yang lain saling menegasikan dan mensubordinasikan. Ketenteraman dan kasih sayang akan semakin jauh apabila salah satu dari pasangan merasa tidak mendapatkan kesejahteraan lahir batin, dan apabila tidak ditemukan hubungan komunikatif yang sinergis antara suami isteri.

Perkawinan sebagai institusi yang secara praktis menyatukan laki-laki dan perempuan pada level keagamaan ini sebenarnya merupakan definisi yang paling dekat dengan makna generik dari istilah perkawinan itu sendiri yakni al-dham wa 'l-jam" , artinya mengumpulkan. Mengumpulkan istri dan suami dalam kesatuan hakikat dan praktis, tanpa ada hirarkhi apalagi subordinatif.

Dengan demikian, di sini tidak dikenal konsep pemegang kepemilikan yang sentralistik pada diri laki-laki. Di sini tidak pula dikenal konsep domi-

${ }^{1}$ Wahbah al-Zuhayly, al-Figh al-Islami wa`adillatuh, Juz VII, (Damaskus: Dar Al Fikr, 1989), h. 28. 
nasi oleh salah satu pihak. Oleh karena itu sangat tepat apabila Wahbah al Zuhaili membuat definisi nikah sebagai ikatan yang ditentukan oleh syari (pembuat hukum) yang memungkinkan laki-laki untuk istimta '(mendapatkan kesenangan seksual) dari isterinya, dan demikian juga bagi perempuan untuk mendapatkan kesenangan seksual dari pihak suaminya. ${ }^{2}$ Definisi dari Wahbah ini merupakan sebuah upaya yang cukup bagus bagi pendefinisian kembali atas definisi-definisi perkawinan yang agak condong ke arah patriarkhi.

\section{Poligami dalam Hukum Perkawinan}

Berdasarkan Undang-Undang Nomor 1 Tahun 1974 tentang Perkawinan dinyatakan bahwa perkawinan adalah sah apabila dilakukan menurut hukum masing-masing agamanya dan kepercayaannya itu. Adapun pencatatan perkawinan dibuktikan dengan adanya buku nikah sifatnya hanya administratif belaka dan tidak mempengaruhi sahnya perkawinan. Meskipun bersifat administratif, pencatatan perkawinan merupakan kebijakan ulil amri yang harus didukung dan ditaati. Menurut Hazairin ${ }^{3}$, termasuk kebijakan ulul amri adalah ketentuan yang berwujud pembentukan garis hukum baru bagi keadaan-keadaan baru menurut tempat dan waktu dengan berpedoman pada kaidah hukum yang ada dalam al-Qur'an dan Hadits.

Subtansi dari hukum perkawinan ini mengambil dari fiqh munakahat yang terdapat di beberapa kitab-kitab klasik yang banyak beredar dan diamalkan oleh komunitas muslim di Indonesia, bersamaan dengan datangnya agama Islam di Indonesia.

Di dalam fiqh munakahat dengan varian madzhab hukum yang ada terdapat ketentuan yang mengatur tentang berbagai persoalan yang terkait dengan perkawinan, termasuk juga ketentuan poligami yakni suami mempunyai isteri lebih dari satu. Ketentuan tentang poligami yang terdapat dalam fiqh munakahat klasik ini kemudian diakomodir dalam regulasi tentang perkawinan di Indonesia.

Menurut ketentuan yang terdapat dalam beberapa literatur fiqh klasik dikemukakan bahwa ketentuan tentang poligami sangat terkait dengan asas

${ }^{2}$ Ibid., h. $29-32$.

${ }^{3}$ Hazairin, Tujuh Serangkai Tentang Hukum, (Jakarta: Tintamas, 1984), h. 65. 
keadilan suami. Keadilan suami ini meliputi keadilan dalam distribusi kesejahteraan lahir batin terhadap isteri-isterinya, terhadap anak-anaknya, mertua-mertuanya dan juga keluarga isteri dan isterinya. Asas keadilan merupakan asas yang sangat penting dalam hukum Islam. Menurut penulis, karena pentingnya asas keadilan ini maka asas ini disebut sebagai asas dari semua asas hukum Islam. ${ }^{4}$ Perkawinan dalam konsep fiqh munakahat tidak hanya melibatkan sosok suami dan sosok isteri semata, tetapi perkawinan merupakan pertalian antara dua keluarga besar suami dan isteri dalam segala akibat sosial yang ditimbulkannya.

Di dalam hukum perkawinan dianut bahwa pada azasnya dalam suatu perkawinan seorang pria hanya boleh mempunyai seorang isteri. Seorang perempuan hanya boleh mempunyai seorang suami. Akan tetapi apabila dikehendaki oleh pihak yang bersangkutan (suami maupun isteri) maka pengadilan dapat memberikan izin kepada suami untuk beristeri lebih dari seorang.

Pengadilan hanya akan memberikan izin kepada suami untuk beristeri lebih dari satu apabila (Pasal 4 UU No. 1/1974):

1. Isteri tidak dapat menjalankan kewajibannya sebagai isteri;

2. Isteri mendapat cacat badan atau penyakit yang tidak dapat disembuhkan;

3. Isteri tidak dapat melahirkan keturunan.

Berdasarkan ketentuan Pasal 4 ini, menurut penulis, nampak jelas dan terkesan bahwa isteri menjadi objek penderita. Ketentuan Pasal 4 ini apabila dilihat dari kaca mata hakikat perkawinan, nampak sekali bahwa suami sangat arogan, egois, dan ingin menang sendiri. Nampak bahwa konstruksi sosial sangat mewarnai regulasi tentang poligami ini. Bagaimana tindakan hukumnya apabila ketentuan Pasal 4 tersebut mengarah pada kondisi fisik dan psikis suami. Suami tidak dapat menjalankan kewajibannya sebagai suami; suami mendapat cacat badan atau penyakit yang tidak dapat disembuhkan; dan suami tidak mampu memberikan keturunan (karena mandul atau yang sejenisnya). Oleh karena itu menurut penulis perlu adanya rekonstruksi terhadap persyaratan poligami ini.

${ }^{4}$ Ali Imron, Hukum Islam dalam Pembangunan Hukum Nasional, (Semarang: Badan Penerbit UNDIP, 2007), h. 38. 
Disamping persyaratan tersebut, hukum perkawinan juga menambahkan persyaratan (Pasal 5):

1. Ada persetujuan dari isteri atau isteri-isteri;

2. Adanya kepastian bahwa suami mampu menjamin keperluan hidup isteri-isteri dan anak-anak mereka;

3. Adanya jaminan bahwa suami akan berlaku adil terhadap isteri-isteri dan anak-anak mereka.

Ayat berikutnya menyebutkan bahwa persetujuan dari isteri atau isteri tersebut tidak diperlukan bagi seorang suami apabila isteri atau isteriisterinya tidak mungkin diminta persetujuannya dan tidak dapat menjadi pihak dalam perjanjian, atau apabila tidak ada kabar dari isterinya selama sekurang-kurangnya 2 (dua) tahun, atau karena sebab-sebab lainnya yang perlu mendapat penilaian dari hakim pengadilan.

Pengaturan tentang beristeri lebih dari satu juga mendapat pengaturan khusus dalam Kompilasi Hukum Islam (KHI) akan tetapi isinya lebih banyak menyangkut aspek hukum prosedural sebagaimana yang telah diatur dalam Peraturan Pemerintah Nomor 9 Tahun 1975. ${ }^{5}$

Persyaratan yang diminta oleh Pasal 5 UU Nomor 1 Tahun 1974 item 1 dan 2 secara lahiriyah dapat terukur secara matematis, akan tetapi untuk persyaratan item 3 ukuran yang digunakan adalah psikis yang memang tidak mungkin bisa terukur. Mungkinkan suami mampu berbuat adil terhadap isteri-isteri dan anak-anaknya? Allah Dzat yang menciptakan alam semesta telah menggariskan bahwa watak karakter suami sebagai manusia biasa tidak mungkin (wa lan) untuk mampu (tastati $u$ ) bisa berbuat adil terhadap isteri-isterinya. Hal ini terekam dalam al Quran surat al-Nisa' [4] ayat 129 yang artinya "Dan kamu sekali-kali tidak akan dapat berlaku adil di antara isteri- isteri (mu), walaupun kamu sangat ingin berbuat demikian, karena itu janganlah kamu terlalu cenderung (kepada yang kamu cintai), sehingga kamu biarkan yang lain terkatung-katung. Dan jika kamu mengadakan perbaikan dan memelihara diri (dari kecurangan), maka sesungguhnya Allah Maha Pengampun lagi Maha Penyayang".

${ }^{5}$ Abdurrahman, Kompilasi Hukum Islam di Indonesia, (Jakarta: Akademika Presindo, 1992), h. 73. 
Berdasarkan ayat 129 tersebut menurut penulis meskipun syari'at Islam membuka peluang adanya poligami, akan tetapi hal tersebut tidaklah mungkin manusia biasa (basyariyah) mampu untuk melaksanakannya karena sifat keterbatasan yang dimiliki manusia untuk berbuat adil terhadap isteri-isterinya dan keluarganya. Hanya para nabi dan rasul yang diberi kalebihan oleh Allah untuk mampu melaksanakannya.

\section{Menggugat Poligami dalam Hukum Perkawinan}

Salah satu persoalan figh munakahat yang sampai saat ini masih ramai menjadi bahan diskusi adalah soal poligami. Poligami merupakan persoalan pelik yang dihadapi oleh kaum perempuan dan Islam.

Dasar hukum pemberlakuan poligami dalam fiqh munakahat adalah ayat al Quran surat al-Nisa' [4] ayat 3 yang artinya: "Dan jika kamu takut tidak akan dapat berlaku adil terhadap (hak-hak) perempuan yang yatim (jika kamu mengawininya), maka kawinilah perempuan-perempuan (lain) yang kamu senangi: dua, tiga, atau empat. Kemudian jika kamu takut tidak akan dapat berlaku adil, maka (kawinilah) seorang saja......".

Mengenai poligami ini, ada ungkapan menarik yang dikutip al Bajuri dari Ibn 'Abd al-Salam yang mengatakan: "Dahulu, pada zaman syari'at Musa, perempuan dibolehkan dinikahi tanpa batas untuk kemaslahatan laki-laki. Pada zaman syari'at Isa, tidak diperbolehkan dinikahi kecuali satu untuk kemaslahatan perempuan. Pada masa syari'at Nabi kita, kedua maslahat tersebut dipelihara" ${ }^{6}$

Adapun hikmah di balik itu adalah sebagai berikut. Pada masa Musa kemaslahatan laki-laki didahulukan karena rezim Fir'aun telah membunuh anak-anak lelaki dan meninggalkan banyaknya perempuan. Pada masa Isa dimenangkan kemaslahatan perempuan karena Isa diciptakan tanpa ayah (bila abin), maka pantaslah apabila syari'at Isa memenangkan kemaslahatan perempuan. $^{7}$ Adapun pada zaman syari'at Muhammad lahir, hikmah dibolehkannya nikah empat adalah menenteramkan secara bertahap psikis masyarakat Arab pada waktu itu yang masih berbudaya patriarki dan

${ }^{6}$ Syaikh Ibrahim al Bajuri, Hasyiyah al Bajuri libni Qasim, Jilid II, (Semarang: Toha Putra, t.th.), h. 93.

${ }^{7}$ Ibid. 
beristeri banyak. Jadi yang menjadi pertimbangan utama ada tidaknya atau boleh tidaknya atau diizinkan tidaknya poligami adalah nilai kemaslahatan. Kemaslahatan menjadi titik sentral dalam penilaian para pihak dalam mengambil keputusan hukum.

Dari kutipan di atas, tampak al Badjuri ingin menunjukkan keadilan syari'at Islam, yakni syari'at yang mensinergikan gagasan-gagasan kemaslahatan umum dalam satu wadah Islam, dan mengoreksi syari'atsyari'at pra Islam yang tidak membawa kemaslahatan. Pendapat dari Ibn Abd al-Salam di atas juga dimaksudkan sebagai upaya rasionalisasi fiqh Islam terhadap poligami. Namun secara historis apa yang dikemukakannya tidak didukung bukti yang kuat. Pendapat ini bahkan berlawanan dengan sumber lain yang menunjukkan bahwa poligami merupakan lompatan kebijakan sekaligus koreksi Islam atas syari'at sebelumnya, yang membolehkan laki-laki mengawini perempuan dengan seenaknya tanpa batas.

Pada masa Nabi ada seorang sahabat yang bernama Ghilan al Tsaqafi. Dia mempunyai sepuluh orang isteri, kemudian hal ini dilaporkan kepada Nabi dan Nabi menyuruhnya untuk mengambil empat dari sepuluh isteri tersebut. Riwayat ini membuktikan bahwa poligami memang merupakan respons sosiologis dan antropologis al-Qur'an terhadap masyarakat saat itu. Bilangan empat janganlah diartikan sebagai batas maksimal untuk masa sekarang, tetapi batas maksimal untuk masa lalu atau pada waktu ayat tersebut diturunkan.

Pada umumnya, dalam membahas persoalan poligami ini, hampir semua kitab fiqh (baik yang muhtasar maupun yang mu tabarah) menyoroti sisi kebolehan (mubahah) nya saja, tanpa mengkritisi kembali hakikat di balik kebolehan tersebut, baik secara historis maupun sosiologis dan antropologis. Fenomena seperti ini, merupakan kesalahan para ulama fiqh dalam memahami prinsip keadilan dalam surat al-Nisa' [4] ayat 3 tersebut.

Prinsip keadilan inilah yang di garis bawahi Muhammad 'Abduh ketika dia mengeluarkan fatwa yang sangat menghebohkan untuk ukuran zamannya pada waktu itu. Fatwa 'Abduh yang dikeluarkan pada tahun $1298 \mathrm{H}$ tersebut secara panjang lebar dikutip oleh 'Ali Ahmad al-Jurjawi dalam bukunya yang sangat terkenal Hikmah al-Tasyri' wa-Falsafatuhu. 'Abduh mengatakan bahwa syari'at Muhammad memang membolehkan laki-laki mengawini empat perempuan sekaligus, jika laki-laki tersebut 
mengetahui kemampuan dirinya untuk berbuat adil. Jika tidak mampu berbuat adil, tidak dibolehkan beristeri lebih dari satu. Dalam hal ini, 'Abduh mengutip ayat yang artinya "kemudian jika kamu takut tidak akan dapat berlaku adil maka -kawinilah- seorang saja". Menurut "Abduh, apabila seorang laki-laki tidak mampu memberikan hak-hak isterinya, rusaklah struktur rumah tangga dan kacaulah penghidupan keluarga. Padahal, tiang utama dalam mengatur kehidupan rumah tangga adalah adanya kesatuan dan saling menyayangi antar anggota keluarga. ${ }^{8}$

Dari kutipan al Jurjawi atas fatwa Muhammad 'Abduh di atas, nampaknya 'Abduh sangat menekankan pada keadilan yang kualitatif dan hakiki; seperti pera-saan sayang, cinta dan kasih yang semuanya ini tidak dapat diukur dengan angka-angka. Hal ini sesuai dengan makna yang dikandung dalam istilah yang di-gunakan oleh al-Qur'an, yaitu kalimat adalah, yang memang memiliki makna yang lebih kualitatif. Adapun keadilan yang dikemukakan oleh para ahli fiqh lebih cenderung bersifat kuantitatif, yang sebenarnya lebih tepat untuk kata qistun (adil). ${ }^{9}$ Keadilan kuantitatif ini bersifat rentan karena sifatnya mudah berubah. Keadilan kuantitatif tersebut tampak dalam aturan-aturan fiqh mengenai poligami, misalnya tentang pembagian jatah rezeki secara merata di antara isteri-isteri yang dikawini, pembagian jatah hari (giliran), dan sebagainya. Para ahli fiqh tidak memperhatikan aspek-aspek yang kualitatif yang justru sangat menentukan, misalnya, rasa cinta, tidak pilih kasih, memihak, dan sebagainya. Padahal keadilan kualitatif ini seharusnya menjadi prioritas utama. Orang yang bisa mencapai keadilan kuantitatif belum tentu bisa mencapai keadilan kualitatif.

Kealpaan ulama-ulama fiqh untuk mendefinisikan keadilan kualitatif ini terlihat pada, misalnya, per-nyataan 'Abdurrahman al Jazairi dalam kitab al-Fiqh 'ala Mazahib al-Arba'ah. Dia menyatakan bahwa mempersamakan hak atas kebutuhan seksual dan kasih sayang di antara isteri-isteri yang dikawini bukanlah kewajiban bagi orang yang berpoligami; karena sebagai manusia orang tidak akan mampu berbuat adil dalam membagi kasih sayang.

\footnotetext{
8’Ali Ahmad al Jurjawi, Hikmah al Tasyri wa Falsafatuhu, (Beirut: Dar al Fikr, t.th.), h. 12.

${ }^{9}$ Syafiq Hasyim, Hal-hal Yang Tak Terpikirkan tentang Isu-isu Keperempuanan dalam Islam, (Bandung: Mizan, 2001), h. 161 - 162.
} 
Firman Allah dalam surat al-Nisa' [4] ayat 129 berbunyi "Dan kamu sekali-kali tidak akan dapat berlaku adil di antara isteri-isteri (mu), walaupun kamu sangat ingin berbuat demikian, karena itu janganlah kamu terlalu cenderung (kepada yang kamu cintai) sehingga kamu biarkan yang lain terkatung-katung. Dan jika kamu mengadakan perbaikan dan memelihara diri (dari kecurangan), maka sesungguhnya Allah Maha Pengampun lagi Maha Penyayang”.

Kasih sayang sangat bersifat naluriah (instingtif), oleh karenanya lepas dari kontrol akal keadilan manusia. Hal ini menurut ahli fiqh merupakan kebenaran dari firman Allah surat al-Nisa' [4] ayat 129 di atas. Oleh ulama figh, ayat ini ditafsirkan sebagai ketidakmampuan manusia untuk berbuat adil dalam hal kasih sayang dan cinta. Untuk itu, ulama fiqh tidak memasukkan perasaan kasih sayang dan cinta sebagai kategori keadilan (kualitatif) yang harus dipenuhi oleh seorang suami yang berpoligami.

Sudah barang tentu ini adalah penafsiran yang sepihak. Apabila diperhatikan secara cermat, ayat tersebut justru merupakan peringatan Allah akan pentingnya nilai keadilan yang bersifat kualitatif. Poligami secara jelas memang diperbolehkan oleh Allah dalam surat al-Nisa' [4] ayat 3 .

Boleh berpoligami tetapi dengan syarat keadilan. Menurut Plato, keadilan mengandung pengertian hubungan yang harmonis dengan berbagai organisme sosial. ${ }^{10}$ Bahkan Hans Kelsen secara ekstrim berpendapat bahwa keadilan tidak dapat didefinisikan karena keadilan merupakan sebuah tatanan ideal yang tidak rasional. ${ }^{11}$ Suami yang akan berpoligami harus mampu mewujudkan nilai keadilan dalam keluarga. Keluarga merupakan sebuah bagian dari organisme sosial. Anggota keluarga (termasuk suami) harus menundukkan keinginan dan kesukaan pribadinya kepada kesatuan maslahat kolektif keluarga.

Persyaratan keadilan dalam poligami, menurut penulis sulit bahkan tidak akan bisa dicapai manusia karena hakikat dari keadilan adalah kemampuan manusia untuk mendistribusikan kebutuhan-kebutuhan yang bersifat kualitatif (cinta kasih dan sayang) dan kuantitatif (nafkah, tempat tinggal, dan yang sejenisnya) secara sama kepada isteri-isterinya dan keluarganya sebagai sebuah kesatuan organik yang kolektif.

\footnotetext{
${ }^{10}$ Muhammad Muslehuddin, Filsafat Hukum Islam dan Pemikiran Orientalis, (Yogya: Tiara Wacana, 1997), h. 36.

${ }^{11}$ Friedmann, Legal Theory, (Oxford: Clarendon Press, 1993), h. 345.
} 
Para fuqaha klasik menganggap kebolehan untuk menikah sampai empat isteri membawa kekuatan hukum, sedangkan tuntutan berlaku adil (secara kualitatif) untuk mereka semata-mata dianggap anjuran, tanpa efek ikatan tertentu. Dengan demikian, para fuqaha mengambil ayat-ayat khusus (kebolehan poligami) sebagai aturan yang mengikat dan prinsip-prinsip umum (keadilan kualitatif) sebagai anjuran.

Penempatan prinsip umum dari aturan-aturan khusus (dalam alQur'an) tentunya harus didasarkan pada kondisi sosial di mana ayat itu diturunkan. Ketika al-Qur'an memberikan alasan-alasan ditentukannya suatu hukum, baik langsung maupun tidak langsung, maka memahami alasanalasan tersebut menjadi suatu hal penting agar bisa menarik prinsip umum. Aspek-aspek yang terkandung di dalam ayat, selama aspek ini menjadi latar belakang turunnya ayat, harus dikaji dalam teori sosio-moralnya secara komprehenship, dengan tetap berdasar pada al-Qur'an dan hadits. ${ }^{12}$

Lebih dari itu, bilangan dua, tiga dan empat pada surat al-Nisa' [4] ayat 3 tersebut harus dipahami sebagai finalitas (ihdad) yang hanya berlaku pada masa awal Islam (masa kenabian). Ayat tersebut sangat bersifat sosiologis, historis dan ekonomis. Sebagaimana penulis sebutkan di atas, jumlah empat merupakan terobosan yang berani dari Islam sekaligus sebagai koreksi atas tradisi poligami tanpa batas yang berlaku pada saat itu. Oleh karenanya dengan melihat berbagai aspek dan tatanan sosial budaya masyarakat pada saat kini, penulis berkeyakinan bahwa dengan tetap menjunjung tinggi maqashid al syari ah dan terwujudnya distribusi kesejahteraan lahir batin suami isteri dan keluarga maka ketentuan poligami sudah tidak relevan lagi. ${ }^{13}$

Kemudian, kalau dilihat dari sisi kebolehan poligami, berdasarkan perspektif munasabah ayat bi 'l-ayat yang dibolehkan adalah mengawini jandajanda yang mempunyai anak yatim. Akan tetapi, dalam realitasnya ayat ini oleh para pemegangnya sering dieksploitasi untuk kepentingan pribadi. Mohammad Syahrur mengemukakan bahwa isu krusial dalam ayat-ayat poligami adalah keadilan pada janda-janda dan anak-anak yatim. ${ }^{14}$

\footnotetext{
${ }^{12}$ Rahman, Towards Reformulating the Methodologi of Islamics Law, (Chicago: The University of Chicago Press, 1982), h. 221.

${ }^{13}$ Ali Imron, Kedudukan Wanita dalam Hukum Keluarga, (Semarang: Badan Penerbit UNDIP, 2007), h. 71-76.

${ }^{16}$ Mohammad Syahrur, al Kitab wa al Qur`an: Qira`a Mu ashira, (Kairo dan Damaskus: Sina Lil Nash, 1992), h. 598-600.
} 
Menurut penulis, perlu penelaahan ulang terhadap hukum poligami, sebab poligami yang dibolehkan oleh agama pada tataran kehidupan seharihari telah dieksploitasi demi kepentingan nafsu seksual manusia dan jauh dari kemaslahatan keluarga secara sosial. Menurut Hasbi, di mana saja ada kemaslahatan, maka di situlah terdapat syari'at Islam. ${ }^{15}$ Ini berarti bahwa apabila ternyata praktik poligami jauh dari kemaslahatan keluarga secara konstruksi sosial, berarti poligami dalam implementasinya bukan merupakan syari'at Islam.

\section{E. Kesimpulan}

Hakikat perkawinan adalah reunifikasi dua sosok manusia beda jenis kelamin yang terdiri dari unsur jiwa dan raga menyatu menjadi satu dalam sebuah bingkai untuk mewujudkan apa yang disebut kesejahteraan lahir batin.

Regulasi perkawinan menganut azas bahwa seorang pria hanya boleh mempunyai seorang isteri begitu juga sebaliknya. Pengadilan dapat memberikan izin kepada suami untuk beristeri lebih dari seorang dengan persyaratan tertentu.

Keadilan merupakan kemampuan suami untuk mendistribusikan kebutuhan kualitatif dan kuantitatif secara sama kepada isteri, anak, dan keluarga. Keadilan sebagai syarat poligami sulit bahkan mustahil bisa dicapai. Poligami identik dengan eksploitasi terhadap perempuan demi kepentingan dan keserakahan nafsu seksual.[]

\section{Daftar Pustaka}

Abdurrahman, Kompilasi Hukum Islam di Indonesia, Jakarta: Akademika Presindo, 1992.

Ali Ahmad al Jurjawi, Hikmah al Tasyri wa Falsafatuhu, Beirut: Dar al Fikr, t.th.

Ali Imron, Hukum Islam dalam Pembangunan Hukum Nasional, Semarang: Badan Penerbit UNDIP, 2007.

${ }^{15}$ TM Hasbi Ash Shiddieqy, Falsafah Hukum Islam, (Jakarta: Bulan Bintang, 1986), h. 331. 
Ali Imron, Kedudukan Wanita dalam Hukum Keluarga, Semarang: Badan Penerbit UNDIP, 2007.

Friedmann, Legal Theory, Oxford: Clarendon Press, 1993.

Hazairin, Tujuh Serangkai Tentang Hukum, Jakarta: Tintamas, 1984.

Mohammad Syahrur, al-Kitab wa al-Qur'an: Qira'a Mu'ashira, Kairo dan Damaskus: Sina Lil Nash, 1992.

Muhammad Muslehuddin, Filsafat Hukum Islam Dan Pemikiran Orientalis, Yogya: Tiara Wacana, 1997.

Rahman, Towards Reformulating the Methodologi of Islamics Law, Chicago: The University of Chicago Press, 1982.

Syafiq Hasyim, Hal-Hal Yang Tak Terpikirkan Tentang Isu-Isu Keperempuanan Dalam Islam, Bandung: Mizan, 2001.

Syaikh Ibrahim al Bajuri, Hasyiyah al Bajuri libni Qasim, Jilid II, Semarang: CV Toha Putra, t.th.

TM Hasbi Ash Shiddieqy, Falsafah Hukum Islam, Jakarta: Bulan Bintang, 1986.

Wahbah Al Zuhayly, Al Figh Al Islami Wa'adillatuh, Juz VII, Damaskus: Dar Al Fikr, 1989. 
